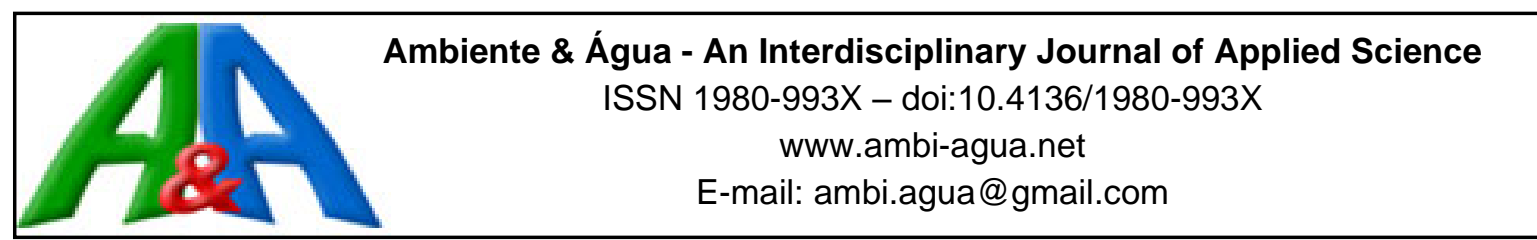

\title{
Synergistic bromothymol blue dye degradation with hydrodynamic cavitation and hydrogen peroxide $\left(\mathrm{HC}-\mathrm{H}_{2} \mathrm{O}_{2}\right)$
}

\author{
ARTICLES doi:10.4136/ambi-agua.2518
}

Received: 17 Jan. 2020; Accepted: 20 Apr. 2020

\begin{abstract}
Polyane Ribeiro Machado ${ }^{1}$; ; Thiago Vinícius Ribeiro Soeira1 ${ }^{1 D}$;
Fausto de Souza Pagan ${ }^{2}$; Geoffroy Roger Pointer Malpass ${ }^{3}$; Julio Cesar de Souza Inácio Gonçalves ${ }^{4}$; ; Deusmaque Carneiro Ferreira ${ }^{4 *(D}$
\end{abstract}

${ }^{1}$ Programa de Pós-Graduação em Ciência e Tecnologia Ambiental. Instituto de Ciências Exatas e Tecnológicas. Universidade Federal do Triângulo Mineiro (UFTM), Avenida. Dr. Randolfo Borges Júnior, $\mathrm{n}^{\circ} 1400$, CEP: 38064-200, Uberaba, MG, Brazil. E-mail: pollyaneribeiro@ hotmail.com, tvribeiro88@ hotmail.com ${ }^{2}$ Programa de Pós-Graduação Multicêntrico em Química de Minas Gerais. Instituto de Ciências Exatas e Tecnológicas. Universidade Federal do Triângulo Mineiro (UFTM), Avenida Dr. Randolfo Borges Júnior, n 1400, CEP: 38064-200, Uberaba, MG, Brazil. E-mail: faustopagan1 @ hotmail.com

${ }^{3}$ Departamento de Engenharia Química. Instituto de Ciências Tecnológicas e Exatas. Universidade Federal do Triângulo Mineiro (UFTM), Avenida Dr. Randolfo Borges Júnior, n 1400, CEP: 38064-200, Uberaba, MG, Brazil. E-mail: geoffroy.malpass@uftm.edu.br

${ }^{4}$ Programa de Pós-Graduação em Ciência e Tecnologia Ambiental. Instituto de Ciências Exatas e Tecnológicas. Departamento de Engenharia Ambiental. Universidade Federal do Triângulo Mineiro (UFTM). Avenida Dr. Randolfo Borges Júnior, n 1400, CEP: 38064-200, Uberaba, MG, Brazil. E-mail: julio.goncalves@uftm.edu.br *Corresponding author. E-mail: deusmaque.ferreira@uftm.edu.br

\begin{abstract}
This study assessed the degradation of bromothymol blue in a Venturi device based on a hybrid process that combines hydrodynamic cavitation $(\mathrm{HC})$ and hydrogen peroxide $\left(\mathrm{H}_{2} \mathrm{O}_{2}\right)$. A Rotatable Central Composite Design (RCCD) was used to optimize the following variables: pressure, reaction time and molar ratio of hydrogen peroxide. Degradation efficiencies were evaluated based on Chemical Oxygen Demand (COD) and color removals before and after Venturi treatment. Maximum COD (93.42\%) and color $(93.28 \%)$ removals were observed at 4.0 bar inlet pressure, at a treatment time of 25 minutes and at $\mathrm{H}_{2} \mathrm{O}_{2} /$ effluent (dye) molar ratio of 30:1. The hydrodynamic cavitation/hydrogen peroxide system has great potential to remove normally recalcitrant organic pollutants.
\end{abstract}

Keywords: advanced oxidation process, rotatable central composite design, Venturi.

\section{Degradação sinérgica do corante azul de bromotimol com cavitação hidrodinâmica e peróxido de hidrogênio $\left(\mathrm{CH}-\mathrm{H}_{2} \mathrm{O}_{2}\right)$}

\section{RESUMO}

O objetivo do presente trabalho foi avaliar a degradação do corante azul de bromotimol em dispositivo Venturi empregando processo combinado: cavitação hidrodinâmica e peróxido de hidrogênio. O Planejamento Composto Central (PCC) foi utilizado para otimizar as variáveis; pressão, tempo de reação e proporção molar de peróxido de hidrogênio. Foram avaliadas as eficiências de degradação a partir das análises da Demanda Química de Oxigênio (COD) e a remoção de cor antes e após o tratamento no Venturi. Obteve-se a condição de 
remoção máxima de COD (93.42\%) e cor (93.28\%) para pressão de entrada de 4.0 bar, com tempo de tratamento de 25 minutos e proporção molar de $\mathrm{H}_{2} \mathrm{O}_{2}$ e efluente (corante) de 30:1. $\mathrm{O}$ sistema de cavitação hidrodinâmica, combinado com peróxido de hidrogênio, tem grande potencial para remover compostos orgânicos de difícil degradação (inércia química).

Palavras-chave: planejamento composto central, processo oxidativo avançado, Venturi.

\section{INTRODUCTION}

Dyes are widely used in different sectors such as the food industry, tattooing, textile and paper production, tanning, and others. A large proportion of the applied dyes are discharged into water bodies due to nonexistent and/or inadequate industrial wastewater treatment systems. It is estimated that approximately 2 tons, or about $20 \%$, of all dyes consumed by the Brazilian textile industry, are annually discarded as effluent (Dallago et al., 2005).

Dyes often damage aquatic ecosystems after reaching water bodies. Among the possible effects are increased recalcitrant organic levels, visual pollution, acute and chronic toxicity, and reduced photosynthetic activity due to restrictions to the passage of solar radiation (Saxena $e t$ al., 2018; Mendes et al., 2015).

Dyes are compounds capable of inhibiting the metabolic activity of microorganisms, a fact that reduces their likelihood of being naturally degraded in the environment. Incomplete degradation processes can lead to the formation of by-products that are highly toxic to humans and to aquatic organisms (Dillari et al., 2016).

Given the difficulties in degrading dyes and the environmental damage that can be caused by them, studies focused on investigating different treatment technologies have been performed to reduce costs and increase the effective degradation of these compounds. Among the investigated technologies are ozonation (Ghuge and Saroha, 2018; Santos et al., 2011), electrochemical (Alves et al., 2014), photodegradation (Castanheira et al., 2017), biological adsorption (Mendes et al., 2015) and biodegradation (Priya et al., 2015).

Hydrodynamic cavitation (HC) is another promising technique for water/wastewater treatment which has been receiving interest in recent years. It is a technique with great potential for several industrial applications and its effectiveness for wastewater treatment has been demonstrated (Joshi and Gogate, 2019; Batista et al., 2017).

Hydrodynamic cavitation (HC) can be understood as a phenomenon of vapor microbubble (cavities) formation, growth and implosion (collapse) in the liquid phase. HC is generated by the passing of liquid through physical constrictions such as orifice plates, a Venturi device, or partially closed valves (Gagol et al., 2018).

$\mathrm{HC}$ produces physicochemical effects that can be used to oxidize pollutants in wastewater. According to Gomes (2015), imploding bubbles play the part of "micro-reactors" that can reach extreme temperatures and pressures in a very short period of time, as well as produce the hydroxyl radical ( $\mathrm{HO}^{\circ}$ ), which is one of the most powerful oxidizers and an excellent chain reaction initiator (Raut-Jadhav et al., 2013). The hydroxyl radical can oxidize virtually all organic and inorganic pollutants found in wastewater due to the high standard reduction potential $\left(\mathrm{E}^{\mathrm{o}}=2.8 \mathrm{~V}\right)$ of this species (Araújo et al., 2016).

As a result of the production of $\mathrm{HO}$, a number of researchers consider $\mathrm{HC}$ as an Advanced Oxidation Process (AOP) (Gagol et al., 2018; Parsa and Zonouzian, 2013; Raut-Jadhav et al., 2013). In addition, the degradation efficiency of $\mathrm{HC}$ reactors can be enhanced by the addition of oxidants such as $\mathrm{H}_{2} \mathrm{O}_{2}$ (Saharan et al., 2011), $\mathrm{CCl}_{4}$ (Chakinala et al., 2008) and $\mathrm{O}_{3}$ (Čehovin et al., 2017). Accordingly, AOPs can be used to treat difficult-to-degrade effluents, as they have high potential to partially or totally degrade recalcitrant species, and increase biodegradability for subsequent in biological treatment systems (Maldonado et al., 2007). 
Given the environmental issues that can take place due to the non-degradation of dyes in wastewater, the discoloration and degradation of bromothymol blue (BTB) dye was investigated based on the use of $\mathrm{HC}$ produced by a Venturi device in combination with $\mathrm{H}_{2} \mathrm{O}_{2}$. The chemical structure of BTB has a cyclic sulfonic ester-bonded aromatic ring and two bromine atom thymol molecules in the ortho position (Figure 1).

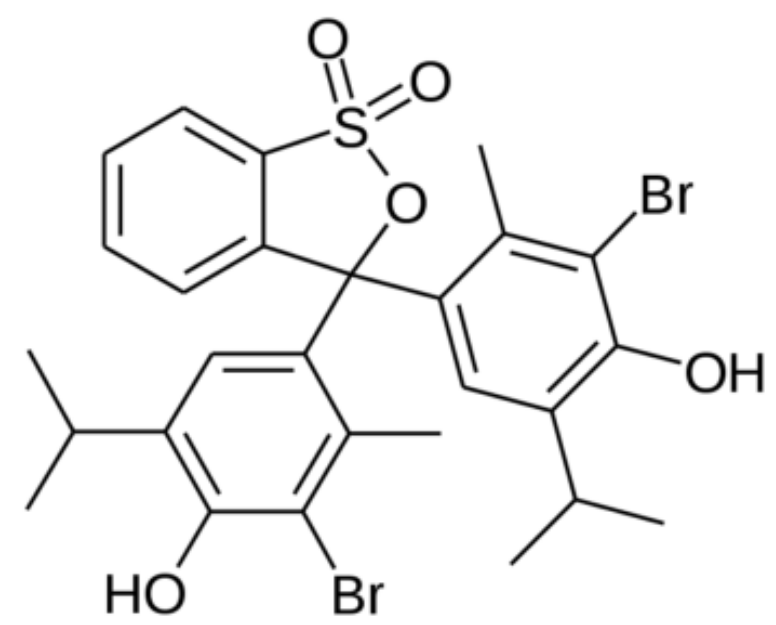

Figure 1. Chemical Structure of BTB.

An experimental procedure using a Rotatable Central Composite Design (RCCD) was employed to optimize the system parameters for BTB removal, namely: Venturi inlet pressure, hydrogen peroxide concentration and reaction time.

\section{MATERIALS AND METHODS}

\subsection{Hydrodynamic cavitation system, device and flow characteristics}

Figure 2A shows the closed circuit hydrodynamic cavitation system, which consists of a $0.075 \mathrm{~m}^{3}$ capacity tank, 2 serial centrifugal pumps - the first $1.0 \mathrm{HP}(\mathrm{KSB}$, Hydrobloc $\mathrm{P})$ and the second 1.5 HP (TH16S), flow control valves (V1 and V2), sampling record (R), pressure gauges (P1 and P2), a Venturi device, and piping and fittings $(\varnothing=32 \mathrm{~mm})$. A copper coil heat exchanger was inserted into the tank to maintain the temperature constant $\left(35 \pm 1{ }^{\circ} \mathrm{C}\right)$. Venturi inlet (P1) and outlet (P2) pressures were measured with a Full Gauge digital controller (PCT400Ri) with a measuring range of 0 to 34.4 bar. The flow rate was controlled by valves $\mathrm{V} 1$ and V2 and measured through a properly calibrated orifice plate (flow coefficient, $\mathrm{Cd},=0.7$ ). The Venturi device was made of acrylic and its dimensions are shown in Figure 2B.

Bromothymol blue degradation (BTB) was analyzed at five different inlet pressures (P1): 0.6, 2.0, 4.0, 6.0 and 6.4 bar. Based on HC studies, the inlet pressure is one of the most important hydraulic parameters used to assess pollutant degradation efficiency (Gagol et al., 2018). The higher the inlet pressure, the greater the vapor volume generated downstream of the Venturi throat. The cavitation intensity was calculated based on the cavitation number $(\mathrm{Cv})$, represented in Equation 1 and is presented in Table 1 with the other Venturi flow features.

$$
C v=\frac{P 2-P v}{1 / 2 \rho V_{0}^{2}}
$$

Where in $C v$ is the cavitation number; $P v$ is the vapor pressure of the liquid $(\mathrm{Pa}) ; \rho$ is the specific mass of the liquid $\left(\mathrm{kg} \mathrm{m}^{-3}\right)$; and $V o$ is flow rate in the Venturi throat $\left(\mathrm{m} \mathrm{s}^{-1}\right)$. \\ IPABH}



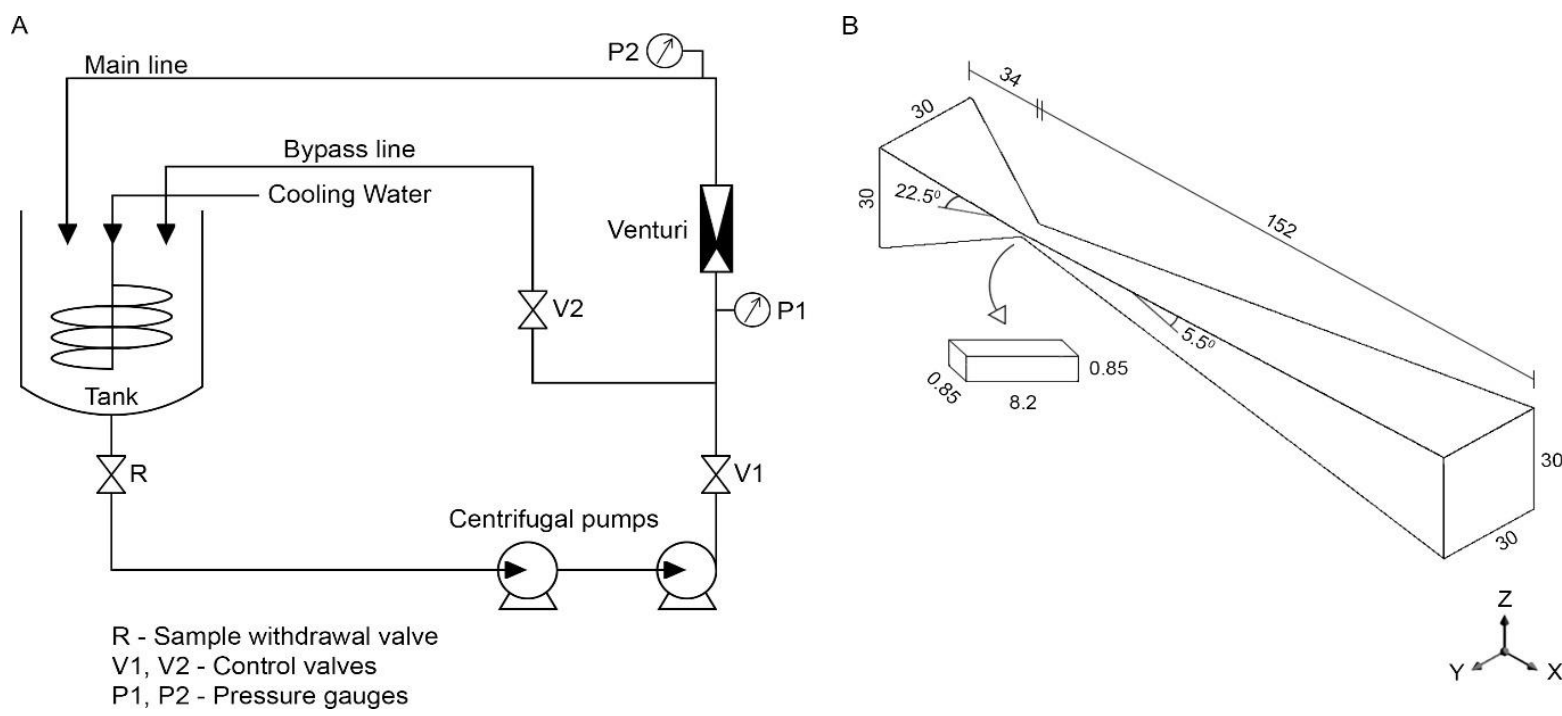

Figure 2. (A) Hydrodynamic cavitation system (without dimensions); and (B) Venturi device (mm).

Table 1. Venturi device flow features.

\begin{tabular}{ccccc}
\hline P1 (bar) & P2 (bar) & Flow rate $\left(\mathbf{L ~ s}^{-\mathbf{1}}\right)$ & Velocity $\left(\mathbf{m ~ s}^{-\mathbf{1}}\right)$ & $\mathbf{C v}(-)$ \\
\hline 0.6 & 0.056 & 0.059 & 8.48 & 2.62 \\
2.0 & 0.059 & 0.155 & 22.30 & 0.38 \\
4.0 & 0.063 & 0.211 & 30.26 & 0.21 \\
6.0 & 0.067 & 0.243 & 34.91 & 0.16 \\
6.4 & 0.067 & 0.249 & 35.65 & 0.15 \\
\hline
\end{tabular}

\subsection{Materials}

Bromothymol blue $\left(\mathrm{C}_{27} \mathrm{H}_{28} \mathrm{Br}_{2} \mathrm{O}_{5} \mathrm{~S}\right.$, 99.98\%) was obtained from Química Moderna Indústria e Comércio EIRELI and used without further purification. A $250 \mathrm{~L}$ saturated solution of Bromothymol blue dye (concentration $=180.51 \mathrm{mg} \mathrm{L}^{-1}$ and COD $=650 \mathrm{mg} \mathrm{L}^{-1}$ ), was prepared using tap water that was not previously purified. Therefore, all HC experiments presented the same initial content of Total Dissolved Solids (TDS). The $\mathrm{pH}$ of the solution was adjusted to 2.5 by addition of sulfuric acid (P.A. 98\%). This measure was adopted due to results reported by Gagol et al. (2018), Raut-Jadhav et al. (2013) and Gogate and Bhosale (2013), according to whom organic degradation is more efficient under acidic conditions.

Hydrogen peroxide ( $30 \% \mathrm{w} / \mathrm{v}$ ) was used as an oxidizing agent and was added at the beginning of each experiment (in batch) and at molar ratios (number of mol peroxide to $1 \mathrm{~mol}$ dye) ranging from 0.1 to 40 .

\subsection{Experimental design}

A Rotatable Central Composite Design (RCCD) was elaborated by taking into consideration two levels, $2^{3}$ factorial points, $2 \times 3$ axial points and 3 repetitions in the central point, thus totaling 17 experiments. Independent variables analyzed in the RCCD were hydrogen peroxide ratio (number of mol peroxide per 1 mol dye), Venturi inlet pressure (bar), hydrodynamic cavitation time (min) and interrelationships. Dependent response variables analyzed for BTB degradation were color reduction and COD reduction rates.

Working variables were coded and decoded (Equation 2) to generate the analysis parameters of the statistical model.

$\frac{X n=(\text { Xreal }-X m i d)}{\Delta \frac{X}{2}}$ 
Where in $X n$ is the coded variable, Xreal is the real variable, Xmid is the midpoint of each variable, $\Delta X$ is the variation between the lower and upper levels of the real variable. Statistical analysis was performed using the software Statistica 7.0 (Stat Soft).

Table 2 shows the experimental matrix, which presents the real and coded values of all experiments.

Table 2. Experimental matrix with real and coded values used in the RCCD.

\begin{tabular}{cccc}
\hline Experiments & Peroxide $\left(\mathbf{m o l} \mathbf{H}_{\mathbf{2}} \mathbf{O}_{\mathbf{2}} \mathbf{~ m o l ~ o f ~} \mathbf{B T B}^{-\mathbf{1}}\right)$ & Time $(\mathbf{m i n})$ & Inlet pressure (bar) \\
\hline 1 & $10(-1)$ & $10(-1)$ & $2(-1)$ \\
2 & $40(+1)$ & $10(-1)$ & $2(-1)$ \\
3 & $10(-1)$ & $30(+1)$ & $2(-1)$ \\
4 & $40(+1)$ & $30(+1)$ & $2(-1)$ \\
5 & $10(-1)$ & $10(-1)$ & $6(+1)$ \\
6 & $40(+1)$ & $10(-1)$ & $6(+1)$ \\
7 & $10(-1)$ & $30(+1)$ & $6(+1)$ \\
8 & $40(+1)$ & $30(+1)$ & $6(+1)$ \\
9 & $50(+\alpha)$ & $20(0)$ & $4(0)$ \\
10 & $0.1(-\alpha)$ & $20(0)$ & $4(0)$ \\
11 & $25(0)$ & $37(+\alpha)$ & $4(0)$ \\
12 & $25(0)$ & $3(-\alpha)$ & $4(0)$ \\
13 & $25(0)$ & $20(0)$ & $6.4(+\alpha)$ \\
14 & $25(0)$ & $20(0)$ & $0.6(-\alpha)$ \\
15 & $25(0)$ & $20(0)$ & $4(0)$ \\
16 & $25(0)$ & $20(0)$ & $4(0)$ \\
17 & $25(0)$ & $20(0)$ & $4(0)$ \\
\hline
\end{tabular}

\subsection{BTB degradation kinetics and analysis methods}

BTB in acid solution is yellow ( $\mathrm{pH} 2.5$ by addition of sulfuric acid (P.A. 98\%)) and presents maximum molar absorptivity at $430 \mathrm{~nm}$. Visible radiation absorption (color) is directly proportional to BTB concentration in the solution, based on the Lambert-Beer Law (Skoog et al., 2002). Color analyses were performed at $\mathrm{pH} 2.5$, at $430 \mathrm{~nm}$, using a spectrophotometer (Biospectro SP-22). COD analysis was based on the closed-tube reflux colorimetric method by APHA et al. (2012).

The BTB degradation kinetics were quantitatively expressed using Equation 3, according to which the degradation rate is a function of the product between the kinetic coefficient $(\mathrm{k})$ and the BTB concentration raised to power $\mathrm{n}$ (reaction order). The kinetic analysis was performed under the optimized experimental condition defined by the RCCD.

$\frac{C_{B T B}}{d t}=-k C_{B T B}^{n}$

Kinetic coefficient and reaction order estimates were calculated based on the differential method suggested by Chapra (2008).

\section{RESULTS AND DISCUSSION}

\subsection{Bromothymol blue degradation}

Table 3 shows the color reduction and COD values recorded for the bromothymol blue dye of the planning matrix, after the combined hydrodynamic cavitation and hydrogen peroxide $\left(\mathrm{H}_{2} \mathrm{O}_{2}\right)$ process. 
Table 3. Bromothymol blue degradation after combined hydrodynamic cavitation and hydrogen peroxide process.

\begin{tabular}{ccccc}
\hline Experiments & BTB $\left(\mathbf{m g ~ L}^{-\mathbf{1}}\right)$ & BTB reduction $(\boldsymbol{\%})$ & $\mathbf{C O D}\left(\mathbf{m g ~ L}^{\mathbf{1}}\right)$ & $\mathbf{C O D}$ reduction $(\boldsymbol{\%})$ \\
\hline 1 & 14.98 & 91.70 & 57.07 & 91.22 \\
2 & 21.66 & 88.00 & 96.52 & 85.15 \\
3 & 17.82 & 90.13 & 59.93 & 90.78 \\
4 & 17.47 & 90.32 & 62.72 & 90.35 \\
5 & 20.61 & 88.58 & 71.30 & 89.03 \\
6 & 15.76 & 91.27 & 45.63 & 92.98 \\
7 & 23.05 & 87.23 & 85.54 & 86.84 \\
8 & 15.29 & 91.53 & 64.94 & 90.01 \\
9 & 12.78 & 92.92 & 47.25 & 92.73 \\
10 & 78.16 & 56.70 & 279.43 & 57.01 \\
11 & 17.20 & 90.47 & 59.93 & 90.78 \\
12 & 27.22 & 84.92 & 105.49 & 83.77 \\
13 & 13.37 & 92.59 & 47.25 & 92.73 \\
14 & 21.64 & 88.01 & 71.30 & 89.03 \\
15 & 12.56 & 93.04 & 42.77 & 93.42 \\
16 & 16.01 & 91.13 & 59.93 & 90.78 \\
17 & 12.13 & 93.28 & 45.17 & 93.05 \\
\hline
\end{tabular}

* Initial BTB concentration (color) $=180.51 \mathrm{mg} \mathrm{L}^{-1}$; Initial COD $=650 \mathrm{mg} \mathrm{L}^{-1}$.

Color and COD reduction percentages appear to be very similar, which indicates that a high level of total combustion/removal is obtained (Miwa, 2006). The current study has made the option to perform a Chi-square $\left(\chi^{2}\right)$ correspondence test, which showed that color and COD reduction levels were not independent at a 95\% significance level $(\mathrm{p}<0.05)$. Thus, the numerical values of these parameters were correlated. Accordingly, only the term 'degradation rate', which corresponds to the mean color and COD reduction rate of each experiment, was taken into consideration for the analysis of experimental results.

As the principal objective of the present study was the optimization of the variables' pressure, reaction time and molar proportion of $\mathrm{H}_{2} \mathrm{O}_{2}$ for $\mathrm{BTB}$ degradation using $\mathrm{HC}$, the nature of possible intermediates was not explored. However, the similarity between color and COD removal values can be explained considering the efficiency of the $\mathrm{HC}$ process in promoting complete BTB mineralization with little intermediate product formation. This type of synergistic effect is often seen when combined AOP processes are used (Alves et al., 2014).

The best experimental result recorded for degradation efficiency was observed in Experiment 15 (approximately 93\%): with a peroxide ratio of 25, cavitation time was 20 min and inlet pressure 4.0 bar. On the other hand, the lowest degradation efficiency was observed in Experiment 10: with a peroxide ratio of 0.1, cavitation time was $20 \mathrm{~min}$ and inlet pressure 4.0 bar. Based on these results, degradation efficiency is significantly reduced at low oxidant concentrations. Alves et al. (2019) used hydrodynamic cavitation to analyze COD reduction efficiency of an effluent whose main constituent was sucrose. Based on their results, 90\% removal efficiency was observed when peroxide/sucrose molar ratio was equal to 20, cavitation time was 25 min and inlet pressure was 4.0 bar. However, such efficiency decreased to $50.9 \%$ when the peroxide/sucrose ratio was equal to zero.

A quadratic regression model was developed based on degradation efficiency data. The model is represented in Equation 4.

$\%$ Degradation $=72.602+96.642 X_{1}+0.982 X_{1}^{2}+1.131 X_{2}-0.023 X_{2}^{2}+3.601 X_{3}-$ $0.312 X_{3}^{2}-2.291 X_{1} X_{2}-16.100 X_{1} X_{3}-0.011 X_{2} X_{3}$ 
The coefficients in Equation 4 were calculated using Student's t-test by taking into consideration a significance level of $95 \%(\mathrm{p}<0.005)$. $\mathrm{X}_{1}$ represents the peroxide variable, $\mathrm{X}_{2}$ represents the cavitation device inlet pressure and $\mathrm{X}_{3}$ represents the time.

According to Equation 4, the linear peroxide parameter recorded the most effective dye degradation, as the variables 'peroxide', 'pressure' and 'time' recorded $95.33 \%, 1.12 \%$ and $3.55 \%$ coefficient weights, respectively. However, the interaction between peroxide and inlet pressure $\left(X_{1} X_{2}\right)$, between peroxide and time $\left(X_{1} X_{3}\right)$ and between pressure and time $\left(X_{2} X_{3}\right)$ had a negative influence on dye degradation. With respect to quadratic terms, only peroxide had a positive effect on dye degradation, a fact that confirmed the importance of optimizing this parameter to enable BTB degradation using a Venturi device.

An $\mathrm{R}^{2}$ value of 0.988 was obtained and indicates that the mathematical model generated in the current study represented $98.88 \%$ of experimental data. The lack-of-fit analysis presented values lower than the significance range set for the model $(\mathrm{p}<0.05)$. The analysis of predicted and observed values presented a pure error of 0.0147 , which was lower than the corresponding normal value (0.029). Waste disposal was trendless and presented random distribution close to the mean. Response surfaces observed for degradation rate based on the interaction between the investigated working parameters are shown in Figure 3.
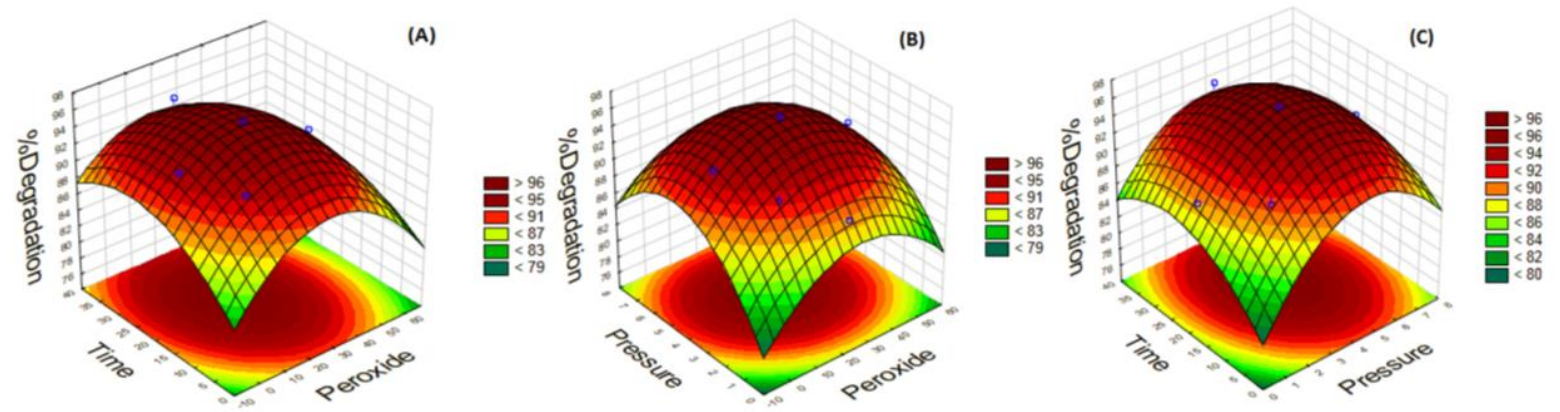

Figure 3. Response surface observed for degradation rate based on the following parameters: (A) time and peroxide; (B) pressure and peroxide; and (C) pressure and time.

According to Figure 3A, a maximum level of degradation was delimited within the investigated time and peroxide ranges. With respect to removal based on pressure and peroxide variables (Figure 3B), there was dispersion of maximum degradation values at the midpoint between peroxide ratio and pressure.

The surface response for BTB degradation based on pressure and time parameters (Figure 3C) also indicates a maximum region near the midpoint of the time window studied. Based on the joint response surface analysis (Figure 3), maximum BTB degradation (critical point) was observed at a time of 25 minutes, pressure 4.0 bar, and peroxide/dye molar ratio equal to 30:1. At the critical point, there was degradation of approximately $93 \%$ of BTB chromophore groups, which are structures responsible for absorbing radiation at $430 \mathrm{~nm}$ (color analysis) and the oxidizable dye structure (COD analysis). Experiments were performed in triplicate under maximized conditions (critical point); results demonstrated a degradation extent of $92.70 \%$, a fact that evidenced the adequate fit and prediction capacity of the generated model (93\%).

The optimum pressure (4.0 bar) observed in the current study did not correspond to the highest pressure ( 6.4 bar) used in the hydrodynamic cavitation system. This result is consistent with other studies available in the literature (Rajoriya et al., 2018; Gogate and Bhosale, 2013; Saharan et al., 2011), according to which pollutant degradation efficiency decreases when inlet pressure is higher than 5.0 bar. This occurs because the higher the inlet pressure, the greater the number of cavities and excess cavities can generate cavitation clouds. Cavitation clouds reduce the degradation rate due to the following reasons: 1) increased likelihood of coalescence between cavities and reduced collapse intensity due to damping of the energy released in the 
implosion; and 2) larger cavities resulting from coalescence escape from the liquid without collapsing. Cavitation clouds were observed by Choi et al. (2018) and Alves et al. (2019).

Although $\mathrm{H}_{2} \mathrm{O}_{2}$ is essential for bromothymol blue degradation, the optimal molar ratio (number of mol peroxide to $1 \mathrm{~mol}$ dye) did not coincide with the highest peroxide concentrations in the cavitation system (molar ratio of 40 and 50). This outcome can be explained by the fact that the excess of peroxide can generate secondary reactions capable of forming radicals with lower degradation potential (Raut-Jadhav et al., 2016; Patil et al., 2014; Bagal and Gogate, 2013). Equations 5, 6, 7 and 8 show the secondary reactions that are likely to occur.

$$
\begin{aligned}
& \cdot \mathrm{OH}+\text { OHcavitation }_{\rightarrow} \mathrm{H}_{2} \mathrm{O}_{2} \\
& \mathrm{H}_{2} \mathrm{O}_{2}+\cdot \text { OHcavitation }_{\rightarrow} \mathrm{HO}_{2}^{\bullet}+\mathrm{H}_{2} \mathrm{O} \\
& \mathrm{HO}_{2}^{\bullet}+\mathrm{HO}_{2}^{\bullet} \text { cavitation }_{\rightarrow} \mathrm{H}_{2} \mathrm{O}_{2}+\mathrm{O}_{2} \\
& \cdot \mathrm{OH}+\mathrm{O}_{2} \text { cavitation }_{\rightarrow} \mathrm{HO}_{2}+\cdot \mathrm{O}
\end{aligned}
$$

These undesirable secondary reactions explain the phenomenon seen in Figures $3 \mathrm{~A}$ and $3 \mathrm{~B}$, wherein the highest degradation efficiency was observed when intermediate $\mathrm{H}_{2} \mathrm{O}_{2}$ values were used (i.e., molar ratio of 30). Thus, it is possible to perform effluent treatment based on hydrodynamic cavitation using lower $\mathrm{H}_{2} \mathrm{O}_{2}$ concentrations, which helps reduce costs with oxidant acquisition and is in line with green-chemistry principles.

\subsection{Analyzing the synergistic effect between hydrodynamic cavitation and hydrogen peroxide}

Experiments without $\mathrm{H}_{2} \mathrm{O}_{2}$ were performed at an inlet pressure of 4.0 bar; whereas the experiment using only $\mathrm{H}_{2} \mathrm{O}_{2}$, at peroxide/dye molar ratio of 30, was performed in batch mode under stirring $(250 \mathrm{rpm})$. Thus, it was possible to evaluate the degradation extent by considering separately the effects of $\mathrm{HC}$ and $\mathrm{H}_{2} \mathrm{O}_{2}$.

Table 4 shows the values for BTB color and COD removal using $\mathrm{HC}$ in the absence of peroxide.

Table 4. Bromothymol blue dye degradation values (\%) in the absence of peroxide.

\begin{tabular}{ccccccc}
\hline Experiments & $\begin{array}{c}\text { Time } \\
(\mathbf{m i n})\end{array}$ & $\begin{array}{c}\text { Inlet pressure } \\
(\mathbf{b a r})\end{array}$ & $\begin{array}{c}\text { Color } \\
\left(\mathbf{m g ~ L}^{-\mathbf{1}}\right)\end{array}$ & $\begin{array}{c}\text { Color } \\
\text { reduction }(\boldsymbol{\%})\end{array}$ & $\begin{array}{c}\text { COD } \\
\left(\mathbf{m g ~ L}^{-\mathbf{1}}\right)\end{array}$ & $\begin{array}{c}\text { COD } \\
\text { reduction }(\%)\end{array}$ \\
\hline 1 & 10 & 4.0 & 117.33 & 35.00 & 419.12 & 35.52 \\
2 & 20 & 4.0 & 107.13 & 40.65 & 376.35 & 42.10 \\
3 & 25 & 4.0 & 106.18 & 41.17 & 375.10 & 42.29 \\
4 & 30 & 4.0 & 105.21 & 41.71 & 370.63 & 42.98 \\
\hline
\end{tabular}

*Initial BTB concentration (color) $=180.51 \mathrm{mg} \mathrm{L}^{-1}$; Initial COD $=650 \mathrm{mg} \mathrm{L}^{-1}$.

According to Table 4, color and COD removal efficiencies did not attain $43 \%$ after 30 minutes of treatment. In the absence of the oxidant, $\bullet \mathrm{OH}$ formation resulted solely from the water molecule dissociation phenomenon caused by pyrolysis. Dissociation only occurred due to the energy resulting from the collapse of cavities (Equation 9).

$$
\mathrm{H}_{2} \mathrm{Ocavitation}_{\rightarrow} \cdot \mathrm{OH}+\cdot \mathrm{H}
$$

Table 5 shows results of the experiment performed using only $\mathrm{H}_{2} \mathrm{O}_{2}$. It can be observed that reduction efficiency sharply decreases in the absence of HC. This result can be explained 
by two reasons: 1) $\mathrm{H}_{2} \mathrm{O}_{2}$ underwent less homolytic fission and generates less $\bullet \mathrm{OH}$ in the absence of $\mathrm{HC}$ (Wang et al., 2009); and 2) Hydrodynamic cavitation increases the effectiveness of $\bullet \mathrm{OH}$ degradation of pollutant molecules as micro-mixing and, consequently, mass transfer are enhanced (Raut-Jadhav et al., 2013).

Table 5. Dye degradation in magnetic stirrer after peroxide addition.

\begin{tabular}{ccccccc}
\hline Experiment & $\begin{array}{c}\mathbf{H}_{2} \mathbf{O}_{2} \\
(\mathbf{m o l})\end{array}$ & $\begin{array}{c}\text { Time } \\
(\mathbf{m i n})\end{array}$ & $\begin{array}{c}\text { Color } \\
\left(\mathbf{m g ~ L}^{-1}\right)\end{array}$ & $\begin{array}{c}\text { Color reduction } \\
(\boldsymbol{\%})\end{array}$ & $\begin{array}{c}\text { COD } \\
\left(\mathbf{m g ~ L}^{-1}\right)\end{array}$ & $\begin{array}{c}\text { COD reduction } \\
(\boldsymbol{\%})\end{array}$ \\
\hline 1 & 30 & 25 & 176.16 & 2.41 & 636.30 & 2.11 \\
\hline
\end{tabular}

*Initial BTB concentration (color) $=180.51 \mathrm{mg} \mathrm{L}^{-1}$; Initial COD $=650 \mathrm{mg} \mathrm{L}^{-1}$.

Table 6 compares the efficiency of the BTB degradation phenomenon based on optimized treatment conditions: pressure equal to 4 bar, $\mathrm{H}_{2} \mathrm{O}_{2}$ equal to 1:30 and time equal to 25 minutes; batch mode using $\mathrm{H}_{2} \mathrm{O}_{2}$; and $\mathrm{HC}$ treatment without $\mathrm{H}_{2} \mathrm{O}_{2}$. The degradation efficiency of the $\mathrm{H}_{2} \mathrm{O}_{2}+\mathrm{HC}$ combination increased $>2$ times in comparison to the use of cavitation alone and it increased $>40$ times when degradation was only performed with $\mathrm{H}_{2} \mathrm{O}_{2}$. This result can be explained by the fact that the combination between $\mathrm{HC}$ and oxidants generates more reactive species (Equation 10), reduced mass transfer resistance and increased turbulence generation. Other authors have also reported increased pollutant degradation when $\mathrm{HC}$ was combined with $\mathrm{H}_{2} \mathrm{O}_{2}$ (Alves et al., 2019; Joshi and Gogate, 2019; Saxena et al., 2018; Saharan et al., 2011).

$$
\mathrm{H}_{2} \mathrm{O}_{2} \text { cavitation } \rightarrow \cdot \mathrm{OH}+\mathrm{OH}
$$

Table 6. Synopsis of the bromothymol blue dye degradation process efficiency.

\begin{tabular}{cccccc}
\hline & $\begin{array}{c}\text { Time } \\
(\mathbf{m i n})\end{array}$ & $\begin{array}{c}\mathrm{H}_{2} \mathbf{O}_{2} \\
(\mathbf{m o l})\end{array}$ & $\begin{array}{c}\text { Inlet pressure } \\
(\text { bar })\end{array}$ & $\begin{array}{c}\text { Color reduction } \\
(\boldsymbol{\%})\end{array}$ & $\begin{array}{c}\text { COD reduction } \\
(\boldsymbol{\%})\end{array}$ \\
\hline Cavitation $+\mathrm{H}_{2} \mathrm{O}_{2}$ & 25 & 30 & 4.0 & 93.28 & 93.42 \\
Cavitation & 25 & - & 4.0 & 40.65 & 42.29 \\
$\mathrm{H}_{2} \mathrm{O}_{2}$ & 25 & 30 & - & 2.41 & 2.11 \\
\hline
\end{tabular}

\subsection{Bromothymol blue dye degradation kinetics}

Figure 4 shows the fit of the kinetic model (Equation 3) to experimental data, which represents the BTB concentration decay over time. The experiment focused on analyzing the kinetic behavior of BTB degradation and was performed under optimized conditions (i.e., pressure $=4$ bar, $\mathrm{H}_{2} \mathrm{O}_{2}=1: 30$, and time $=25$ minutes). Equation 3 fits well with the experimental data $\left(\mathrm{r}^{2}=0.988\right)$. The reaction order observed in this experiment was 3.5 with respect to BTB concentration and the kinetic rate constant was $1.30 \times 10^{-5} \mathrm{mg}^{-2.5} \mathrm{~L}^{2.5} \mathrm{~min}^{-1}$.

Approximately $80 \%$ of the degradation occurred within the first 5 minutes. This outcome can be explained by the fact that $\mathrm{H}_{2} \mathrm{O}_{2}$ was introduced into the batch system at time zero. It can be assumed that $\bullet \mathrm{OH}$ production within the first 5 treatment minutes resulted from two sources, namely: water molecule dissociation due to pyrolysis (Equation 9) and $\mathrm{H}_{2} \mathrm{O}_{2}$ dissociation (Equation 10). After this initial period, $\bullet \mathrm{OH}$ was only produced by $\mathrm{H}_{2}$ Odissociation, since all $\mathrm{H}_{2} \mathrm{O}_{2}$ would have been consumed. This fact, in association with low concentrations of the remaining bromothymol blue, reduced the degradation rate in the treatment period from 5 to 25 minutes.

Figure 5 shows the physical appearance of the bromothymol blue solution before (Vial I) and after treatment under optimized experimental condition (Vial II). Solution $\mathrm{pH}$ was kept at 2.5. Significant color reduction can be observed. Such reduction was possible because the use of $\mathrm{H}_{2} \mathrm{O}_{2}$ in combination with $\mathrm{HC}$ enabled the mineralization of the chemical structure of BTB (Figure 1) due to degradation of chromophore groups (double bonds, functional groups) that account for radiation absorption (color) at $430 \mathrm{~nm}$. 


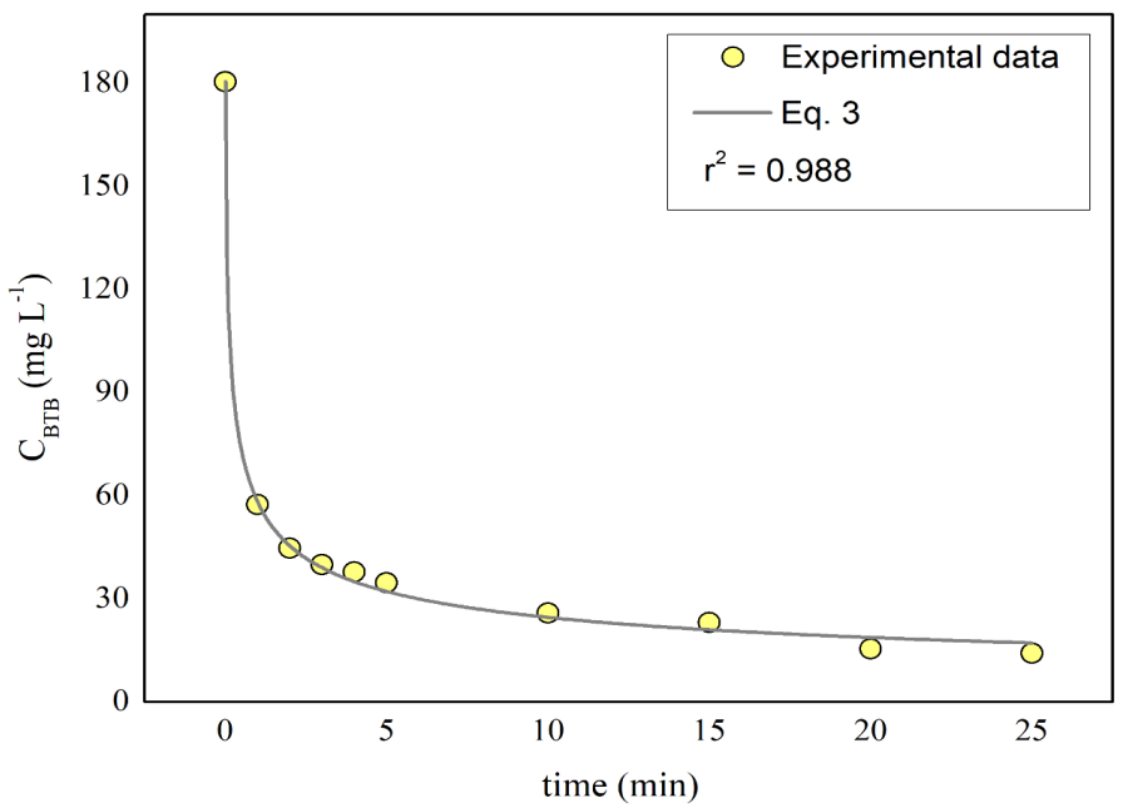

Figure 4. Removal of bromothymol blue dye as a function of time. Optimized experimental conditions: pressure $=4$ bar, $\mathrm{H}_{2} \mathrm{O}_{2}=1: 30$, and time $=25$ minutes.

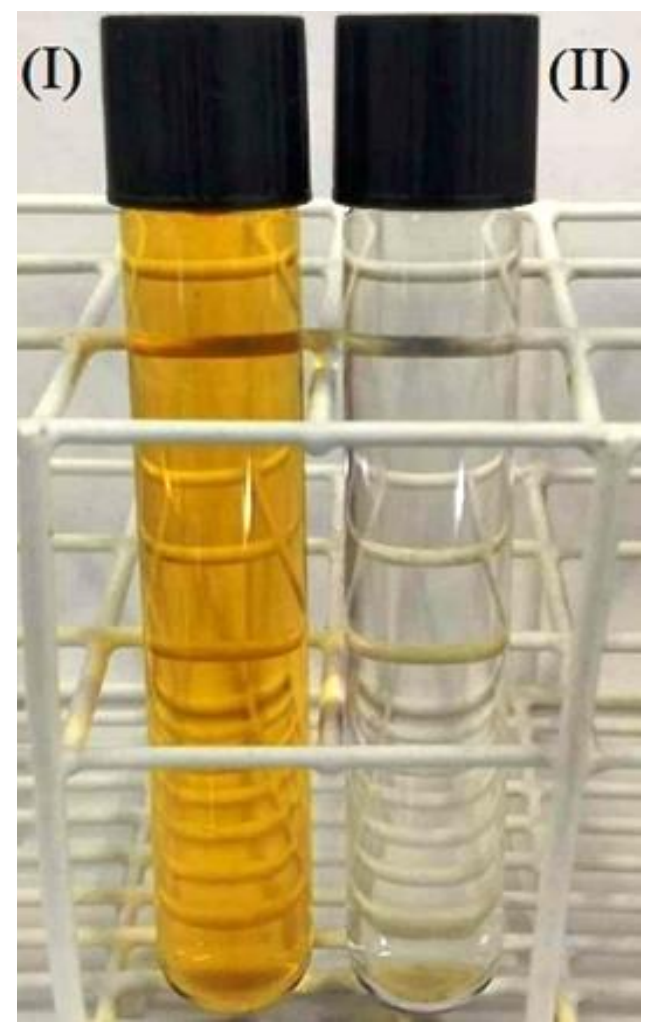

Figure 5. Comparison of bromothymol blue dye color before (I) and after (II) treatment.

\section{CONCLUSION}

This study investigated the efficiency of the combination of hydrodynamic cavitation and $\mathrm{H}_{2} \mathrm{O}_{2}$ to remove color and COD from a bromothymol blue solution. The experiments were 
conducted in a closed-circuit experimental apparatus and the cavitation phenomenon was generated by means of a Venturi device. Results of the experiments found that:

1. Hydrodynamic cavitation in the presence of $\mathrm{H}_{2} \mathrm{O}_{2}$ attained color and COD removals > $90 \%$.

2. Color and COD reduction were more efficient in the combined process - positive synergism.

3. Optimized dye color and COD reduction conditions were observed at 25 minutes of sample recirculation at a dye/peroxide molar ratio of 1:30 and pressure of 4 bar.

4. This method can effectively remove color from tannery effluents. However, results depend on the type of dye to be degraded, as well as on the composition, concentration and other components found in the effluent.

5. Venturi reactors may be used as a promising alternative to treat industrial effluents and as an effective treatment to be applied to difficult-to-degrade wastes.

\section{ACKNOWLEDGEMENT}

The authors are grateful to the National Council for Scientific and Technological Development (CNPq). Process: 421746/2018-1.

\section{REFERENCES}

ALVES, P. A.; JOHANSEN, H. D.; AQUINO NETO, S.; ANDRADE, A. R.; MOTHEO, A. J.; MALPASS, G. R. P. Photo-assisted Electrochemical Degradation of TextileEffluent to Reduce Organic Halide (AOX) Production. Water, Air, \& Soil Pollution, v. 225, p. 2144-2155, 2014. https://doi.org/10.1007/s11270-014-2144-1

ALVES, P. H. L.; SILVA, P. S. L.; FERREIRA, D. C.; GONÇAVES, J. C. S. I. COD removal from sucrose solution using hydrodynamic cavitation and hydrogen peroxide: a comparison between Venturi device and orifice plate. Revista Brasileira de Recursos Hídricos, v. 24, n. 12, p. 1-8, 2019. https://doi.org/10.1590/2318-0331.241920180147

APHA; AWWA; WEF. Standard Methods for the examination of water and wastewater. 22nd ed. Washington, 2012. 1496 p.

ARAÚJO, K. S.; ANTONELLI, R.; GAYDECZKA, B.; GRANATO, A. C.; MALPASS, G. R. P. Processos oxidativos avançados: uma revisão de fundamentos e aplicações no tratamento de águas residuais urbanas e efluentes industriais. Revista Ambiente \& Água, v. 11, n. 2, p. 387-401, 2016. http://dx.doi.org/10.4136/ambi-agua.1862

BAGAL, M. V.; GOGATE P. R. Degradation of 2,4-dinitrophenol using a combination of hydrodynamic cavitation, chemical and advanced oxidation processes. Ultrasonics

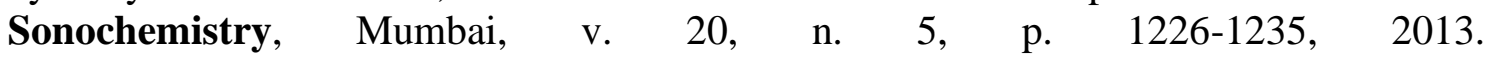
https://doi.org/10.1016/j.ultsonch.2013.02.004

BATISTA, M. D.; ANHÊ, A. C. B. M.; GONÇALVES, J. C. S. I. Use of hydrodynamic cavitation for algae removal: effect on the inactivation of microalgae belonging to genus Scenedesmus. Water, Air, \& Soil Pollution, v. 228, n. 11, p. 443, 2017. https://doi.org/10.1007/s11270-017-3624-X 
CASTANHEIRA, B.; TRINDADE, F. J.; ANDRADE, L. S.; NANTES, I. L.; POLITI, M. J.; TRIBONI, E. R.; BROCHSZTAIN, S. Dye photodegradation employing mesoporous organosilicas functionalized with 1,8-naphthalimides as heterogeneous catalysts. Journal of Photochemistry and Photobiology A: Chemistry, v. 332, n. 8, p. 316-325, 2017. https://doi.org/10.1016/j.jphotochem.2016.08.030

ČEHOVIN, M.; MEDIC, A.; SCHEIDELER, J.; MIELCKE, J.; RIED, A.; KOMPARE, B.; ŽGAJNAR, G. A. Hydrodynamic cavitation in combination with the ozone, hydrogen peroxide and the UV-based advanced oxidation processes for the removal of natural organic matter from drinking water. Ultrasonics Sonochemistry, v. 37, p. 394-404, 2017. https://doi.org/10.1016/j.ultsonch.2017.01.036

CHAKINALA, A. G.; GOGATE, P. R.; CHAND, R.; BREMNER, D. H.; MOLINA, R.; BURGESS, A. E. Intensification of oxidation capacity using chloroalkanes as additives in hydrodynamic and acoustic cavitation reactors. Ultrasonics Sonochemistry, v. 15, n. 3, p. 164-170, 2008. https://doi.org/10.1016/j.ultsonch.2007.02.008

CHAPRA, S. C. Surface water-quality modeling. Long Grove: Waveland, 2008. 844 p.

CHOI, J.; CUI, M.; LEE, Y.; KIM, J.; SON, Y.; KHIM, J. Hydrodynamic cavitation and activated persulfate oxidation for degradation of bisphenol A: kinetics and mechanism. $\begin{array}{llllll}\text { ChemicalEngineeringJournal, } & \text { v. } & 338, & \text { p. }\end{array}$ https://doi.org/10.1016/j.cej.2018.01.018

DALLAGO, R. M.; SMANIOTTO, A.; OLIVEIRA, L. C. A. Resíduos sólidos de curtumes como absorventes para remoção de corantes em meio aquoso. Química Nova, v. 28, n. 3, p. 433-437, 2005. https://doi.org/10.1590/S0100-40422005000300013

DILARRI, G.; DE ALMEIDA, É. J. R.; PECORA, H. B.; CORSO, C. R. Removal of dye toxicity from an aqueous solution using an industrial strain of saccharomyces cerevisiae (Meyen). Water, Air, \& Soil Pollution, v. 227, n. 8, p. 269, 2016. https://doi.org/10.1007/s11270-016-2973-1

GAGOL, M.; PRZYJAZNY, A.; BOCZKAJ, G. Waste treatment by means of advanced oxidation process based on cavitation - A review. Chemical Engineering Journal. v. 338, p. 599-627, 2018. https://doi.org/10.1016/j.cej.2018.01.049

GHUGE, S. P.; SAROHA, A. K. Catalytic ozonation of dye industry effluent using mesoporous bimetallic Ru-Cu/SBA-15 catalyst. Process Safety and Environmental Protection, v. 118, p. 125-132, 2018. https://doi.org/10.1016/j.psep.2018.06.033

GOGATE, P. R.; BHOSALE, G. S. Comparison of effectiveness of acoustic and hydrodynamic cavitation in combined treatment schemes for degradation of dye wastewaters. ChemicalEngineeringandProcessing: ProcessIntensification, v. 71, p.59-69, 2013. https://doi.org/10.1016/j.cep.2013.03.001

GOMES, A. S. Cavitação Hidrodinâmica para tratamento de águas. 2015. 57f. Dissertação (Mestrado em Energia e Ambiente) - Faculdade de Ciências e Tecnologia. Universidade de Coimbra, Coimbra, 2015.

JOSHI S. M.; GOGATE P. R. Intensification of industrial wastewater treatment using hydrodynamic cavitation combined with advanced oxidation at operating capacity of 70L. $\begin{array}{llllll}\text { Ultrasonics Sonochemistry, } & \text { v. } & 52, & \text { p. } & 375-381,\end{array}$ https://doi.org/10.1016/j.ultsonch.2018.12.016 
MALDONADO, M. I.; PASSARINHO, P. C.; OLLER, I.; GERNJAK, W.; FERNÁNDEZ, P.; BLANCO, J.; MALATO, S. Photocatalytic degradation of EU priority substances: A comparison between $\mathrm{TiO}_{2}$ and Fenton plus photo-Fenton in a solar pilot plant. Journal of Photochemistry and Photobiology A: Chemistry, v. 185, n. 2-3, p.354-363, 2007. https://doi.org/10.1016/j.jphotochem.2006.06.036

MENDES, C. R.; DILARRI, G.; PELEGRINI, R. T. Aplicação da biomassa Saccharomyces cerevisiae como agente adsorvente do corante Direct Orange 2GL e os possíveis mecanismos de interações adsorbato/adsorvente. Matéria (Rio de Janeiro), v. 20, n. 4, p. 898-908, 2015. https://doi.org/10.1590/S1517-707620150004.0095

MIWA, D. W.; MALPASS, G. R. P.; MACHADO, S. A. S.; MOTHEO, A. J. Electrochemical degradation of carbaryl on oxide electrodes. WaterResearch, v. 40, p. 3281-3289, 2006. https://doi.org/10.1016/j.watres.2006.06.033

PARSA, J. B.; ZONOUZIAN, S. A. E. Optimization of a heterogeneous catalytic hydrodynamic cavitation reactor performance in decolorization of Rhodamine B: application of scrap iron sheets. Ultrasonics Sonochemistry, v. 20. p. 1442-1449, 2013. https://doi.org/10.1016/j.ultsonch.2013.04.013

PATIL, P. N.; BOTE, S. D.; GOGATE, P. R. Degradation of imidacloprid using combined advanced oxidation processes based on hydrodynamic cavitation. Ultrasonics $\begin{array}{lllllll}\text { Sonochemistry, } & \text { v. } & 21, & \text { n. } & 5, & \text { p. } & 1770-1777,\end{array}$ https://doi.org/10.1016/j.ultsonch.2014.02.024

PRIYA, E. S.; SELVAN, P. S.; UMAYAL, A. N. Biodegradation studies on dye effluent and selective remazol dyes by indigenous bacterial species through spectral characterisation. Desalination and Water Treatment, v. 55, n. 1, p. 241-251, 2015. https://doi.org/10.1080/19443994.2014.913999

RAJORIYA, S.; BARGOLE, S.; GEORGE, S.; SAHARAN, V. K. Treatment of textile dyeing industry effluent using hydrodynamic cavitation in combination with advanced oxidation reagents. Journal of Hazardous Materials, v. 344, p. 1109-1115, 2018. https://doi.org/10.1016/j.jhazmat.2017.12.005

RAUT-JADHAV, S.; BADVE, M. P.; PINJARI, D. V.; SAINI, D. R.; SONAWANE, S. H.; PANDIT, A. B. Treatment of the pesticide industry effluent using hydrodynamic cavitation and its combination with process intensifying additives $\left(\mathrm{H}_{2} \mathrm{O}_{2}\right.$ and ozone). Chemical Engineering Journal, v. 112, p. 4505-4514. 2016. https://doi.org/10.1016/j.cej.2016.03.019

RAUT-JADHAV, S.; SAHARAN, V. K.; PINJAR, D.; SONAWANE, S.; SAINI, D.; PANDIT A. Synergetic effect of combination of AOP's (hydrodynamic cavitation and $\mathrm{H}_{2} \mathrm{O}_{2}$ ) on the degradation of neonicotinoid class of insecticide. Journal of Hazardous Materials, v. 261, p. 139-147, 2013. https://doi.org/10.1016/j.jhazmat.2013.07.012

SAHARAN, V. K.; BADVE, M. P.; PANDIT, A. B. Degradation of reactive red 120 dye using hydrodynamic cavitation. ChemicalEngineeringJournal, v. 178, p. 100-107, 2011. https://doi.org/10.1016/j.cej.2011.10.018

SANTOS, P. K. dos; FERNANDES, K. C.; FARIA, L. A.; FREITAS, A. C.; SILVA, L. M. da. Descoloração e degradação do azo corante vermelho grlx-220 por ozonização. Quim. Nova, v. 34 , n. 8 , p. 1315-1322, 2011. https://doi.org/10.1590/S010040422011000800004 
SAXENA, S.; SAHARAN, V. K.; GEORGE S. Enhanced synergistic degradation efficiency using hybrid hydrodynamic cavitation for treatment of tannery waste effluent. Journal of $\begin{array}{llllll}\text { Cleaner Production, } & \text { v. 198, p. 1406-1421, }\end{array}$ https://doi.org/10.1016/j.jclepro.2018.07.135

SKOOG, D. A.; HOLLER, F. J.; NIEMAN, T. A. Princípios de Análise Instrumental. 5th ed. Porto Alegre: Booman, 2002.

WANG, X.; ZHANG, S.; LI, S. Decolorization of reactive brilliant Red K-2BP in aqueous solution by using hydrodynamic cavitation. Environmental Engineering Science, v. 26, n. 1, p. 53-60, 2009. https://doi.org/10.1089/ees.2007.0201 